\title{
DE
} DE GRUYTER OPEN

\section{FISCAL DECENTRALIZATION AND DELIVERY OF PUBLIC SERVICES: EVIDENCE FROM EDUCATION SECTOR IN PAKISTAN}

\author{
RAUF Abdur \\ KIE, UAJK, Pakistan \\ KHAN Amara Akram \\ MPhil Scholar, KIE, UAJK, Pakistan
}

\author{
ALI Sher \\ Islamia College and University Peshawar, Pakistan \\ QURESHI Ghulam Yahya \\ KIE, UAJK, Pakistan \\ AHMAD Dilshad \\ COMSAT, Veharri Campus, Pakistan \\ ANWAR Numera \\ MPhil Scholar, Women University Bagh, Pakistan
}

\begin{abstract}
:
Fiscal Decentralization is the devolution of fiscal assignments to lower governments for high growth and better delivery of public services. The current study covering the period from 1972 to 2009 is an attempt to find out the impacts of fiscal decentralization on public services deliveries in Pakistan. Public services are proxy by Gross enrollment at primary school level while fiscal decentralization by fiscal transfer and expenditure sides of devolution. Using time series data, it is found that the individual impacts of fiscal transfer are although insignificant but still support the theoretical proposition regarding fiscal decentralization and public services relationship while delegation of expenditure responsibilities helps in improving the gross enrollment at primary school level. Furthermore the study evident that complete delegation of fiscal responsibilities to lower governments enhance enrollment ratio in Pakistan.
\end{abstract}

Key words: Fiscal Decentralization, Public Services, Education, ARDL 


\section{Introduction}

Fiscal Decentralization (FD) is one of the important impetus for desirable delivery of public services. It is the devolution of fiscal or financial responsibilities that occur from upper government to the lower governments. It is viewed that fiscal decentralization increase efficiency by bringing competition, decrease corruption by strongly connecting voters and politicians and thus bringing transparency. Various researchers investigated the growth and decentralization relationship but very few studies has been conducted in the field of investigation of fiscal decentralization and public services especially education sector.

In a decentralized system the central policies are reduced and the masses excess is increased to the local information and thus make a rational decision which reflects the true picture of the community. By this the coordination amongst the various sectors also improve which helps in accountability and thus the educational programs can be easily implement which further affects the overall performance of education sectors,( Litvack and Seddon 1999 and Lieberman 2002).

As the local bodies became responsible and accountable to the local inhabitants then ultimately they will perform better and efficiently. As these local leaders are closer to the inhabitants of the locality, they are well aware of the local problems and thus can implement the right policy and plan,( Peabody et al. 1999 and World Bank 2004).

As per Oates "Decentralization Theorem" closer the government to the masses better it will deliver. In light of this it can be said that outcomes in a decentralized system will be closer to the local voters (Oates 1985:749) which will further helpful in minimization of the overall discrepancies existed between actual outcomes and the voters policy position.

In light of the above advantages associated with decentralization this particular paper is designed to analyze the proposition that fiscal decentralization helps in better delivery of public services (education) in Pakistan. Rest of the paper is organized as following; second section of the paper describe the relevant literature, data and methodological issues are discussed in third section, results are interpreted in the fourth section of the paper and in the last section discussion and policy recommendations has been discussed.

\section{Literature Review}

Extensive research can be found addressing the impacts of fiscal decentralization. The current section disaggregates the existing literature into studies that have positive, negative and inconclusive findings.

\subsection{Positive Impacts:}

Alderman (1998), conducted his study for Albania and found positive impacts of decentralization on social assistance. Bardhan and Mookherjee (2003) conducted 
their study for India and found that decentralization helps in poverty alleviation in India. Galasso and Ravallion (2001) found that decentralization reduce poverty in Bangladesh. Habibi et. al. (2001) found that fiscal decentralization is helpful for a better delivery of public services in Argentina. Eskeland and Filmer (2002) also found the same results for Argentina. Faguet (2001) concluded that in case of Bolivia fiscal decentralization helps in improvement of public services and helps the masses to access social services more efficiently. Foster and Rosenzweig (2001) also found same results. Isham and Kahkonen (1999) found that when the water services were managed by local community it showed improvements. King and Ozler (1998) found that in case of Nicaragua the school management at local level helped in score achievements. Estache and Sinha (1995) is of the view that public infrastructure expenditure increased with decentralization of authority. Huther and Shah (1996) and Enkolopov and Zhuravskaya (2003) found that fiscal decentralization is helpful in delivering of public services more efficiently.

\subsection{Negative Impacts:}

Ravallion (1998) conclude that in case of Argentina, decentralization caused inequality and these provinces which were poor could not provide public services efficiently. Azfar and Livingston (2002) for Uganda concluded that there are negative impacts of fiscal decentralization on the provision of public services. Similarly West and Wong (1995) also found lower level of delivery of public services through decentralization in the less developed regions of China.

\subsection{Inconclusive Impacts:}

Afzar et al. (2000) conducted the study for Philippines and Uganda and found that the response of local government is insufficient because these governments have limited authority and are confined by several constraints, e.g. face procedural difficulties; they have limited sources of financing etc. Khaleghian (2003) concluded that fiscal decentralization in case of middle income countries reduce the coverage of immunization. Winkler and Rounds (1996) found that decentralization of education responsibilities to the lower governments although resulted in efficiency boost up but on the other hand it reduces the score on cognitive test.

\section{Data and Methodology}

Current study is based annual time series data that cover the period from 1972 to 2009. The data is collected from various issues of economic survey of Pakistan.

Empirical analysis has been made through Autoregressive Distributive lag model (ARDL), developed by Pesaran et al (2001). It gives best results even when the sample size is small as it is the case in this particular study, furthermore the technique is applicable even when the order of integration of variables is different (Pesaran et. al. (2001). The application of the technique is completed in three different stages, at stage one the Cointegration in the model is analyzed and the decision is made on the 
basis of Wald F-statistics. When the calculated value of Wald F-statistics is greater than the tabulated Wald F-statistic at $5 \%$ level of significance the null hypothesis for no long run Cointegration is rejected and vice versa is the case when the calculated value lies below the lower bounds at $5 \%$ level of significance. If the calculated value lies in between upper and lower bounds then it indicates towards inconclusiveness.

Our model for this step is as following;

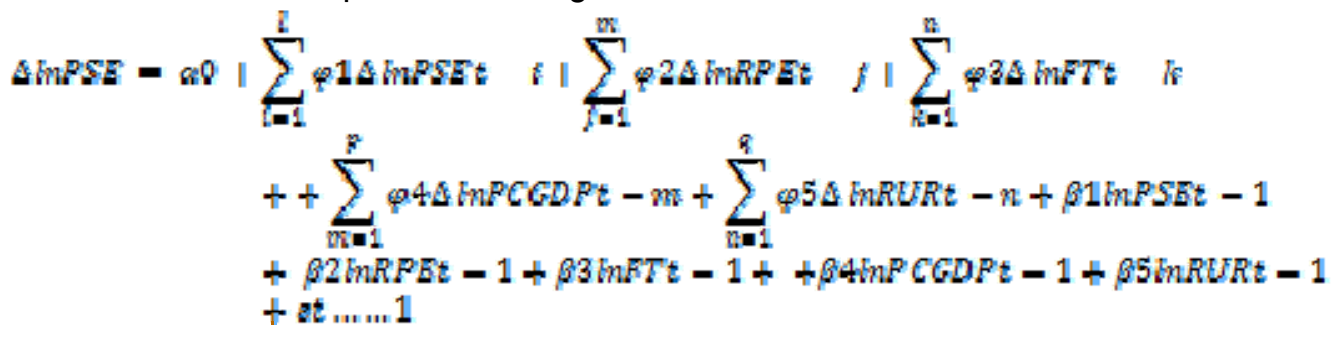

Where the PSE stands for Primary School Enrollment, RPE is Ratio of Provincial Expenditure to total state expenditure, FT is fiscal transfers, PCGFP is per capita gross domestic product and RUR stands for Rural Urban Ratio.

Once it became clear that there exist long run Cointegration, in the second step it is analyzed that how much this relationship meant for one another. Following model is estimated for this purpose;

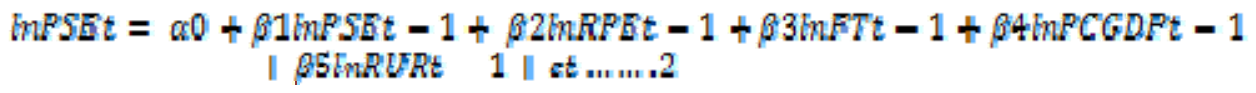

And in the third step the short run eslasticities are extracted from the long run elasticities. The model for short run analysis is as;

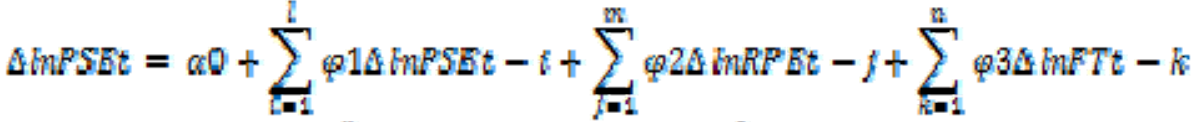

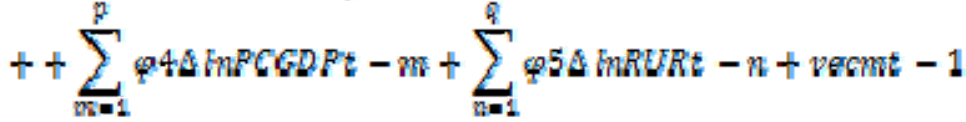

$$
\begin{aligned}
& +a t \ldots 3
\end{aligned}
$$

The subscripts has been discussed previously.

\section{Results and Discussion}

\subsection{Stationarity Analysis:}

To avoid ambiguity in the results first the data is analyzed for unit root by employing Augmented Dicky and Fuller (ADF)Test. Table 1 display the results of ADF test which suggest that except RPE rest of the variables are stationary at lag one while this particular variable (RPE) is stationary at level. 
Table: 1. Unit Root Analysis

\begin{tabular}{|l|l|l|l|l|l|}
\hline \multirow{2}{*}{ Variable } & \multicolumn{2}{l|}{ At Level } & \multicolumn{2}{l|}{ At First Difference } & \multirow{2}{*}{ Decision } \\
\cline { 2 - 5 } & Intercept & $\mathrm{T}+\mathrm{I}$ & Intercept & $\mathrm{T}+\mathrm{I}$ & \\
\hline InPSE & -.08353 & -1.8963 & -5.4015 & -5.3386 & $\mathrm{I}(1)$ \\
\hline InRPE & -4.6238 & -4.6049 & ---- & ---- & $\mathrm{I}(0)$ \\
\hline InFT & -1.4724 & -1.1216 & -8.8566 & -8.7942 & $\mathrm{I}(1)$ \\
\hline InPCGDP & -0.7322 & -1.8890 & -9.0228 & -8.9243 & $\mathrm{I}(1)$ \\
\hline InRUR & -2.0080 & -2.8441 & -3.2813 & -3.6439 & $\mathrm{I}(1)$ \\
\hline
\end{tabular}

\subsection{Lag Length and Criteria Selection:}

Lag length selection criteria has to be find out as the lags capture the dynamics of series. Various criteria are used for lag length. Results of different criterion are displayed in below;

Table: 2. Selection of Lag Length

\begin{tabular}{|c|c|c|c|c|c|}
\hline Lag & LR & FPF & AIC & SC & HQ \\
\hline 0 & -79.58 & 12.13 & 19.71 & 23.89 & 19.96 \\
\hline 1 & 125.63 & $5.46^{*}$ & 4.77 & 6.32 & $7.44^{*}$ \\
\hline 2 & $16.89^{*}$ & 5.82 & $4.02^{*}$ & $5.73^{*}$ & 8.72 \\
\hline
\end{tabular}

* indicates lag order selected by the criterion. LR: sequential modified, FPE: Final prediction error, AIC: Akaike information criterion, SC: Schwarz information criterion, HQ: Hannan-Quinn information criterion.

From the above table it is clear that Akaike Information Criterion (AIC) information criterion at lag length two is the optimal lag length.

\subsection{Long Run Cointegration Analysis:}

In the first step we regress the equation 1 for analyzing long run cointegration in model. We select the model on the basis of AIC at maximum lag length 2. As it is clear from the table 2 that the critical values are easily exceed by our calculated value thus it is concluded that the long cointegration exist in the model. In rest of the cases there exist no cointegration or inconclusive cointegration results are found when we take each variable as a dependent variable. 
Table: 3. Cointegration Decision Analysis

\begin{tabular}{|c|c|c|c|c|c|}
\hline \multirow[t]{2}{*}{ Dependent Variable } & \multirow[t]{2}{*}{ F-Statistic } & \multicolumn{3}{|c|}{ Critical Values } & \multirow[t]{2}{*}{ Cointegration } \\
\hline & & LS & $\mathrm{I}(0)$ & $\mathrm{I}(1)$ & \\
\hline $\mathrm{F}_{P S E}[\mathrm{PSE} / \mathrm{FT}, \mathrm{RPE}, \mathrm{PCGDP}, \mathrm{RUR}, \mathrm{A}]$, & 5.44 & $1 \%$ & 2.12 & 3.23 & Yes \\
\hline $\mathrm{F}_{R P E}[\mathrm{RPE} / \mathrm{FT}, \mathrm{PSE}, \mathrm{PCGDP}, \mathrm{RUR}, \mathrm{A}]$, & .99 & $5 \%$ & 2.45 & 3.61 & No \\
\hline $\mathrm{F}_{F T}[\mathrm{FT} / \mathrm{PSE}, \mathrm{RPE}, \mathrm{PCGDP}, \mathrm{RUR}, \mathrm{A}]$, & .42 & $10 \%$ & 3.15 & 4.43 & No \\
\hline $\mathrm{F}_{P C G D P}[\mathrm{PCGDP} / \mathrm{FT}, \mathrm{RPE}, \mathrm{PSE}, \mathrm{RUR}, \mathrm{A}]$, & 3.47 & ---- & ----- & ----- & Inconclusive \\
\hline $\mathrm{F}_{R U R}[\mathrm{RUR} / \mathrm{FT}, \mathrm{RPE}, \mathrm{PCGDP}, \mathrm{PSE}, \mathrm{A}]$, & 1.70 & $\begin{array}{ll}---- \\
--1\end{array}$ & ----- & ---- & No \\
\hline
\end{tabular}

Note: LS stands for level of significance and Critical values of the F-statistics (CASE III: Unrestricted intercept and no trend) are taken from Pesaran et al. (2001)

\subsection{Estimation of long Run Elasticities:}

To find the long run effects of fiscal decentralization on public service deliveries with respect to education sector in Pakistan we estimate model 2 which is selected on the basis of ARDL $(1,1,2,0,2,1)$ on AIC 2. Regression results suggest that fiscal transfer have positive but insignificant impacts on education sector in Pakistan. The results of devolution of expenditure responsibilities shows that it deliver the education services positively. With increase of $1 \%$ devolution of expenditure responsibilities to the lower government it will enhance the delivery of education services more than unity. Although the impacts of fiscal transfer is insignificant but still it has positive impacts which support the theory of fiscal decentralization about better delivery of public services. Thus in light of the above findings it can be suggest to the government that fiscal responsibilities has to be devolve from the central government to the lower government for a better delivery of public services. Amongst the other control variables it is found that both economic growth and per capita economic growth have positive contribution in the overall enrollment at primary school level. Socioeconomic condition has negative impacts on primary school enrollment and it is understandable as law and order situation, economic and social classification of the Pakistani society, rural-urban life style differences etc all are the factors that contribute to the decline in the enrollment at primary school level.

\subsection{Short Run Dynamics:}

For estimation of the short run impacts of fiscal decentralization on education sector we estimate the model 3 for which we select ARDL (1.1.2.0.2.1) on the basis of AIC at lag 2. It is found that in short run fiscal transfer has negative impacts on primary school enrollment but statistically these results are insignificant which mean statistically fiscal transfer in short span of time although is against the theory but its impacts are of no mean. Expenditure decentralization has positive and significant impacts in the short period of time as well and thus it contributes $16 \%$ in the enrollment at primary school 
level with every $1 \%$ increase in the devolution responsibilities to the lower government. Per capita GDP at level also negatively affect the overall level of enrollment in primary school while at lag period one its value suggest that it will increase the enrollment level in school. Socio-economic conditions in short run have positive impacts on education and its coefficient value shows that it will increase the enrollment by $46 \%$ in the short run. The sign of the equilibrium coefficient model is negative and shows very high speed of adjustment to the long run equilibrium after the previous year shock. It suggest that almost $85 \%$ disequilibrium converge back to equilibrate with the long run equilibrium in the current year.

The diagnostic test results suggest that there is no problem of serial correlation, heteroscadasticity, and also the normality and the functional form of the model is all right. The overall $R^{2}=69 \%$ and adjusted $R^{2}(47 \%)$ suggest that our model fit very well. The CUSUM and CUSUMQ show that over the specified period of time the coefficient is stable in nature.

Table: $4 . \quad$ Diagnostic Tests LM version:

\begin{tabular}{|l|c|c|}
\hline Test Statistic & Chi -Square & Value \\
\hline A- Serial Correlation & $\mathrm{X}^{2}$ & $5.48(.319)$ \\
\hline B- Functional Form & $\mathrm{X}^{2}$ & $4.20(.240)$ \\
\hline C- Normality & $\mathrm{X}^{2}$ & $.71(.701)$ \\
\hline D- heteroscadasticity & $\mathrm{X}^{2}$ & $1.79(.180)$ \\
\hline
\end{tabular}

A: LM Test, B: Ramsey's RESET Test, C: JB Test and D: White Test

\section{Fig.3: CUSUM and CUSUMQ Plots}
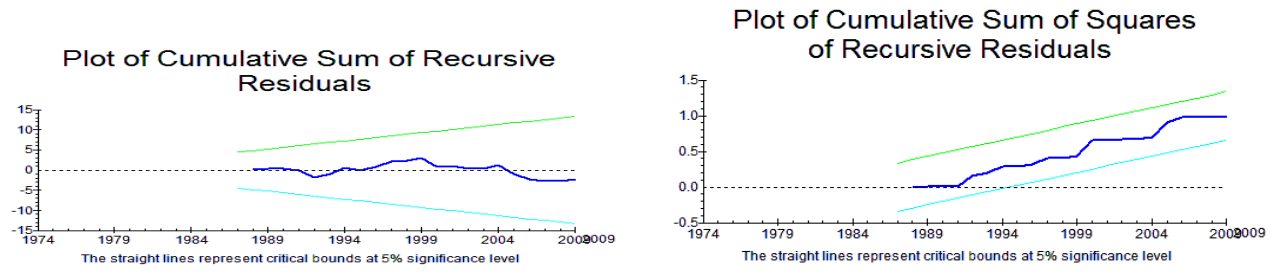

\section{Conclusion}

Current study is based on the analysis of the impacts of fiscal decentralization on public service deliveries in case of Pakistan. Fiscal decentralization is measured by taking fiscal transfer and expenditure devolution as a proxy while public service is measured through education sector and for that this study took gross primary school enrollment. This study uses the annual time series data that range from 1972 to 2009 . For cointegration analysis Bound test for Cointegration is used in this study. First the unit analysis is made and it is found that none of the variable lies outside the prerequisite of Bound Test for Cointegration. And then by using the Bound Test for Cointegration it is found that in long run fiscal transfer have positive impacts to improve 
the delivery of public services. Amongst the measures of fiscal decentralization, fiscal transfers have positive but insignificant impacts on gross enrollment at primary school level while the impacts of expenditure decentralization are not only positive but significant as well. Therefore the central government is advised to follow the policy of decentralization for encouraging the education in Pakistan. This decentralization will increase the confident of the provincial government and they will work freely and efficiently. By giving the authority and autonomy on their own expenditures, the provincial government will generate their own sources of revenue which will not only be helpful and beneficial to the province in itself but the whole country as well.

\section{References}

Alderman, H. (1998). "Social Assistance in Albania: Decentralization and Targeted Transfers".

LSMS Working Paper no. 134,World Bank, Washington D.C.

Azfar, O. and J. Livingston (2002). "Federalist Disciplines or Local Capture? An Empirical Analysis of Decentralization in Uganda." IRIS, University of Maryland.

Azfar, O., S. Kahkonen, and P. Meagher (2001). "Conditions for Effective Decentralised Governance: A Synthesis of Research Findings." IRIS working paper \# 256, University of Maryland.

Azfar,O., S. Kahkonen, J. Livingston, P. Meagher, and D. Rutherford (2000). "Making Decentralization Work: An Empirical Investigation of Governance and Public Services in Uganda." IRIS, University of Maryland.

Azfar,O.,T. Gurgur, S. Kahkonen ,A. Lanyi, and P. Meagher (2000). "Decentralization and Governance: An empirical investigation of public service delivery in the Philippines." IRIS, University of Maryland.

Bardhan, P. and D. Mookherjee, 1998, "Expenditure Decentralization and the Delivery of Public Services in Developing Countries", CIDER Working Paper C98/104.

Bardhan, P. and D. Mookherjee (2003). "Poverty Alleviation Effort of West Bengal Panchayats". http://econ.bu.edu/dilipm/wkpap.htm/epwsumm.pdf

Dickey, D. A. and W. A. Fuller, (1981), "Likelihood ratio statistics for autoregressive time series with a unit root", Econometrica, 49, 1057-1079.

Enikolopov, R. and E. Zhuravskaya (2003). "Decentralization and Political Institutions." http://emlab.berkeley.edu/users/webfac/bardhan/e271_f03/oct6.pdf

Eskeland, G. and D. Filmer (2002). "Autonomy, Participation, and Learning in Argentine Schools: Findings and Their Implications for Decentralization." Policy Research Working Paper 2766. World Bank, Washington DC.

Eskeland, G. and D. Filmer, 2000, "Does Decentralization Improve Learning? Autonomy and Parental Participation in Argentine Schools", mimeo, World Bank.

Estache, A. and S. Sinha (1995). "Does Decentralization Increase Spending on Public Infrastructure?" The World Bank Policy Research Working Paper 1457.

Faguet, J. and Paul G., 2001, "Does Decentralization Increase Government Responsiveness to Local Needs? Evidence from Bolivia", World Bank Policy Research Working Paper No. 2516.

Faguet, J. P. (1997). "Decentralization and Local Government Performance." World Bank/FAO/GTZ paper for the Technical Consultation on Decentralization, Rome. 
Faguet, J.P. (2001). "Does Decentralization Increase Responsiveness to Local Needs? Evidence from Bolivia." Policy Research Working Paper \#2516.World Bank,Washington DC.

Gurgur, T. and A. Shah (2002). "Localization and Corruption: Panacea or Pandora's Box?" In Ehtisham Ahmad and Vito Tanzi,veditors, Managing Fiscal Decentralization, pp. 46-67. Routledge Press, London and New York.

Galasso, E. and M. Ravallion (2001). "Decentralised Targeting of an Anti-Poverty Program." Development Research Group Working Paper.World Bank,Washington D.C.

Galasso, E. and M. Ravallion (1998). "Reaching Poor Areas in a Federal System." Policy Research Working Paper \#1901.World Bank, Washington DC.

Habibi, N., C. Huang, D. Miranda, V. Murillo, G. Ranis, M. Sarkar, and F. Stewart (2001). "Decentralization in Argentina." Economic Growth Center Discussion Paper 825,Yale University.

Huther, J. and A. Shah (1998). "Applying a Simple Measure of Good Governance to the Debate on Fiscal Decentralization." Policy Research Working Paper Number 1894.World Bank,Washington, DC.

Isham, J. and S. Kähkönen (1999). "What Determines the Effectiveness of Community-based Water Projects? Evidence from Central Java, Indonesia on Demand Responsiveness, Service Rules, and Social Capital." University of Maryland.

Khaleghian, P (2003). "Decentralization and Public Services: The Case of Immunization." Policy Research Working Paper 2989.World Bank, Washington, DC.

King, E. and B. Ozler (1998). "What's Decentralization Got To Do With Learning? The Case of Nicaragua's School Autonomy Reform. Development," Research Group Working Paper, World Bank,Washington D.C.

Lieberman, S.S., (2002), "Decentralization and Health in the Philippines and Indonesia: An Interim Report", East Asia Human Development.

Litvack, J. and J. Seddon (1999), "Decentralization Briefing Notes", World Bank Institute.

Narayan, P. K. (2005), "The savings and investment nexus for China: Evidence from cointegration tests," Applied Economics, 37, 1979-1990.

Narayan, P.K., Narayan, S., (2005), "Estimating income and price elasticities of imports for Fiji in a cointegration framework," Economic Modelling, 22, 423-438.

Oates, W. (1972). "Fiscal Federalism”, Hamshire, England: Harcourt Brace Jovanovich 1972.

Oates, W. (1977). "The Political Economy of Fiscal Federalism", Lexington Books, Toronto 1977.

Oates, W. (1999). "An essay on fiscal federalism", Journal of Economic Literature, Vol. XXXVII (September 1999), pp. 1120-1149.

Pesaran, M. H., Shin, Y. and R. J. Smith, (2001), "Bounds testing approaches to the analysis of long run relationships", Journal of Applied Econometrics, 16, 289-326.

Pesaran, M.H. and Shin, Y. (1999), "An autoregressive distributed-led modeling approach to cointegration analysis." In Econometrics and Economic Theory in the 20th Century. The Ragnar Frisch Centennial Symposium, ed. Steinar Strom. Cambridge: Cambridge University Press.

Pakistan. Finance Division, Economic Advisor's Wing: Economic Survey 2010-2011. Islamabad.

Pakistan. Ministry of Education \& MSU. GOP. (2003). Technical Group Meeting on Devolution and Decentralization: Implications for the Education Sector. Islamabad.

Pakistan. Ministry of Education, Education For All Wing. (2002). Facts and Figures: Islamabad.

Pakistan. Ministry of Education. (2003). Education Sector Reforms: Action Plan 2001-2005. Islamabad. 
Pakistan. Ministry of Education. (2001). Education Sector Reforms: Action Plan 2001-2004. Islamabad.

Pakistan. Ministry of Education. (2003). National Plan of Action on Education for All (2001-2015): Islamabad.

Qian, Y. and Weingast (1997). "Federalism as a commitment to preserving market incentives", Journal of Economic perspectives, Vol II, No. 4: 83-92.

Saeed, M. (2007). "Education System of Pakistan and the UK: Comparisons in Context to Inter provincial and Inter-countries Reflections." Bulletin of Education \& Research, 29 (2), 4357.

Shah, A (1998). "Balance, Accountability and responsiveness - Lessons About Decentralization." Policy Research Working Paper No. 2021, December,World Bank, Washington, DC

Shah, A (1998). "Fiscal Federalism and Macroeconomic Governance - For Better or For Worse?" Policy Research Working Paper No. 2005, November,World Bank, Washington, DC

Shah, A. (1994). "The Reform of Intergovernmental Fiscal Relations in Developing and Emerging Market Economies." World Bank, Washington, DC.

Shah, D.(2003). "Decentralization of educational system in Pakistan", Presented at UNESCO Seminar on Decentralization Policies and Strategies in Education held at Buenos Aires, Argentina from 30th June to 3rd July, 2003

Shah, D. (2003). "Decentralization in the education system of Pakistan: Policies and strategies." Paper presented in UNESCO Seminar on Decentralization Policies and Strategies in Education, Buenos Aires, Argentina (p.20-21).

Shami, P.A. \& Hussain, K.S. (2006). "Development of education in Pakistan." Islamabad. Academy of Educational Planning and Management, Ministry of Education (p.11-13 \& 61)

West, L. and C. Wong (1995). "Fiscal Decentralization and Growth Regional Disparities in Rural China: Some Evidence in the Provision of Social Services." Oxford Review of Economic Policy. 11(4): $70-84$.

Winkler, D. "Decentralization in Education: An Economic Perspective." Washington, DC: World Bank, 1989.

Winkler, D. "The Design and Administration of Intergovernmental Transfers: Fiscal

Decentralization in Latin America." World Bank Discussion Paper 235. Washington, DC: World Bank, 1994.

Winkler, D. and Gershberg, Alec. "Education Decentralization in Latin America: The Effects on the Quality of Schooling." Human Development Department LCSHD Paper Series No. 59. Washington, DC: World Bank, 2000.

Winkler, D. and T. Rounds (1996). "Municipal and Private Sector Response to Decentralization and School Choice." Economics of Education Review. 15 (4): 365-376.

Zafar, F. (2003) "Fiscal Devolution in Education. Case Study Reflecting Initial Responses." Islamabad: Ministry of Education. 
Appendix A. Long and Short Run Impacts

Table: 5. Long Run Impacts

Dependent variable is InPSE \{ ARDL(1,1,2,0,2,1) AIC Lag 2\}

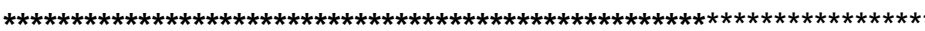

\begin{tabular}{|c|c|c|c|}
\hline Regressor & Coefficient & Standard Error & T-Ratio [Prob] \\
\hline $\ln$ FTP & .1280 & .0772 & $1.6583[.111]$ \\
\hline In $\underline{\mathrm{RPE}}$ & 1.1167 & .2508 & $4.4519[.000]$ \\
\hline $\ln P$ CGDP & .5192 & .1829 & $2.8388[.009]$ \\
\hline $\ln R$ RR & -14.1408 & 7.2762 & $-1.9434[.064]$ \\
\hline $\mathrm{A}$ & 64.1431 & 36.7604 & $1.7449[.094]$ \\
\hline .9646 & & .9018 & $D . W=2.19$ \\
\hline
\end{tabular}

Serial Correlation $=\quad 1.6801(.195) \quad$ Functional Form $=.3732(.541)$

Normality $=\quad .4022(.818) \quad$ Heteroscadasticity $=1.2223(.173)$

Table: 6. ECM Representations:

Dependent variable is $\underline{\mathrm{d} n \mathrm{PSE}}$

\begin{tabular}{lcccc} 
Regressor & Coefficient & Standard Error & T-Ratio & [Prob] \\
\hline dlnFT & -.0362 & .0721 & -.5022 & {$[.620]$} \\
\hline dlnRPE & .1646 & .0927 & 1.7750 & {$[.087]$} \\
\hline dlnRPE1 & -.4019 & .0923 & -4.3538 & {$[.000]$} \\
\hline dlnPCGDP & -.1234 & .0610 & -2.0204 & {$[.053]$} \\
\hline dlnPCGDP1 & .1160 & .0611 & 1.8984 & {$[.068]$} \\
\hline dlnRURAL & 46.4909 & 19.2202 & 2.4189 & {$[.023]$} \\
\hline dA & 36.4666 & 19.8935 & 1.8331 & {$[.078]$} \\
\hline ECM(-1) & -.5685 & .1103 & -5.1533 & {$[.000]$} \\
\hline Adj. R $^{2=} .45$ & F-Stat. $=5.17(.001)$ & D.W. $=2.09$ &
\end{tabular}

